\title{
Traces of Ideology in Translating the Qurān into English: A Critical Discourse Analysis of Six Cases across Twenty Versions
}

\author{
Abdunasir I. A. Sideeg \\ Department of Applied Linguistics, Yanbu University College, KSA \\ E-mail: sidiga@rcyci.edu.sa
}

Received: 14-02- 2015

Published: 01-09- 2015

\author{
Accepted: 23-04- 2015
}

doi:10.7575/aiac.ijalel.v.4n.5p.214
Advance Access Published: May 2015

URL: http://dx.doi.org/10.7575/aiac.ijalel.v.4n.5p.214

\begin{abstract}
This research article aims to explore and critically examine six cases in which traces of ideology are explicitly or implicitly involved in the context of translating the Qurān into English. It attempts to answer questions pertinent to the nature and effect of traces of ideology on translating the Qurān in English and the way they shape the Qurānic message. The article employs a critical qualitative framework that allows for the researcher's subjective interpretations of relevant texts. Critical Discourse Analysis (CDA) is used for the analysis of data as this approach provides a convenient mode of critical thinking to carry out the present thesis. In this article, six texts across twenty versions of the Qurān in English are investigated in terms of their salient features that reflect peculiar ideological readings. Major findings indicate that complex traces of ideology may contribute to a particular choice in translating the salient features in the texts investigated. The case of Helminski, for instance, shows how cultural and linguistic backgrounds, Sufi doctrines, and feminist agendas all combine to produce a radical reading of the Qurān in English where she consistently refers to Allah (SWT) with the combination he/she. Sufi ideologies are crucial in translating some pronouns with controversial references in some Qurānic verses. As well, gnostic interpretations have their own legacy such as the alteration in Khalifa's 'authorized version'. Plus, Neo-Mutazilite and Qurānist traces of ideology significantly contribute to produce alien readings of some Qurānic texts as illustrated in cases (5) and (6) in this research article.
\end{abstract}

Keywords: Qurān, traces of ideology, critical discourse analysis (CDA), sacred feminine, Sufi

\section{Introduction}

Translations of the Qurān in English make a huge corpus if we consider the short history of the formal practice of translating the sacred book of Islam. The first rigorous translation of the Qurān in English was made by Ross in 1649. Yet, over one hundred translations of the Qurān in the English language, complete or partial, have been made since Ross' version emerged. The last five decades witnessed the publication of a plethora of translations made by people with different linguistic, cultural, and ideological backgrounds worldwide. Almost all the translations of the Qurān exhibit significant linguistic variations of multiple sources. These variations reveal the intricacies and difficulties of translating the Qurān, and hence the need to study them using the convenient ontological and epistemological perspectives. Nevertheless, one of the most crucial sources of variations in translating the Qurān is the translator's ideological and sectarian bias which results in the visibility of traces of ideology in translation (Herrag, 2012; Sideeg, 2014).

Contemporary translation studies discloses the strong and significant affinity between translation and ideology. In the words of Aichele (2002) "no translation is ever complete. The selection of possible meanings to be excluded or included is always ideological". In an insightful analysis of the process of translation, Tymoczko and Gentzler (2002) maintain that translation is not simply the act of accurate reproduction of a text but rather, "a deliberate and conscious act of selection, assemblage, structuration, and fabrication - and even, in some cases, of falsification, refusal of information, counterfeiting, and the creation of secret codes" (p. xxi). In the case of translating the Qurān, the role of ideology is crucial. The Qurān itself contains its own unique 'weltanschauung' and distinctive set of ideologies. As Rafiabadi (2003) rightly observes, an interesting fact about the Qurān is that scholars from various sects and faiths contest within the domain of translating the Qurān into English. He quotes Griefenhagen's (1992:284) statement that "by the 20th century, the translation of the Qurān into English became the locus of power struggles, not only between Islam and West, but also between orthodox groups within Islam and heterodox offshoots (p. 215).

Ideology, in Lefevere's (2004) designation, is "a conceptual grid that consists of opinions and attitudes deemed acceptable in a certain society at a certain time, and through which readers and translators approach texts" (p., 5). Hatim and Mason (1997) define ideology as "a body of assumptions which reflects the beliefs and interests of an individual, a group of individuals, a social institution, etc., and which ultimately finds expression in language" (p. 218). Van Dijk 
(2006) maintains that "whatever elle ideologies are, they are primarily some kind of 'ideas', that is, belief systems" (2006, p. 116).

In this article, ideology has a much larger scope than usually formulized in some of the sociological approaches. What Van Dijk (2006) calls the 'belief systems' and Petrescu (2009) calls the "innocent" meaning of the term is preferred in the present paper. In this sense, ideology refers to the totality of the translator's weltanschauung, political agenda, and sectarian or religious views without the value judgment of positive or negative that usually accompanies the term. The term 'traces of ideology' is employed here as ideological perspectives are often hidden or opaque, to be rediscovered and read through the lens of a meticulous, critical, and in-depth analysis of relevant texts and discourse (Sideeg, 2014).

This study aims to explore and critically examine six cases of translating the Qurān into English where traces of ideology are explicitly or implicitly involved. Specifically the article attempts to answer these two broad questions:

1) What is the nature of the traces of ideology that affect translating the Qurān into English?

2) To what extent do traces of ideology shape the Qurānic message in English in the light of the six cases sampled in this study?

\section{Method}

This article employs a 'Critical Discourse Analysis' (henceforth, CDA) approach for the analysis of relevant data. CDA is a "domain of CRITICAL APPLIED LINGUISTICS" where the "relationship between language, power, and ideology is a crucial focal point" (Tavakoli, 2013, p. 129). It is basically interested in the analysis of "opaque" as well as "transparent" structural relationships manifested in language use (Wodak and Meyer, 2009, p. 10). CDA offers a way of critical thinking rather than one single path to carry out a research project as the approach does not "have a unitary theoretical framework" (Van Dijk, 2001, p. 353). In this sense, CDA is neither quantitative nor qualitative, for the approach embraces a variety of methods and approaches that work toward a critical interpretation that uncovers the hidden motivations of a text/discourse. CDA is used here within the article's qualitative framework which is "fundamentally interpretive" allowing research outcome to be "ultimately the product of the researcher's subjective interpretations of data" (Dörnyei, 2007, p. 39).

Six texts are purposively selected from twenty versions of the Qurān in English in this article. Versions included are listed below:

1. Abdel Haleem, M. S: The Qurān

2. Ahmed, A. Al-Qurān: a contemporary translation

3. Ahmed, S. The Qurān as it Explains itself

4. Arberry, A.J.: The Koran interpreted

5. Asad, M.: The message of the Qurān

6. Bakhtiar, L.: The sublime Qurān

7. Bweley and Bweley: The noble Qurān: a new rendering of its meaning in English.

8. Busool, A.N.: The wise Qurān: a new translation

9. Dawood, N. J.: the Koran

10. Haque-Khan: Kanz-ul-Eeman

11. Helminski, C. A.: The light of dawn: daily readings from the holy Qurān
12. Hulusi-I: Decoding the Quran: a unique Sufi interpretation

13. Kahlifa, R.: Quran: the final testament, authorized English version of the original

14. Kidwai, A.: What is in the Qurān? Message of the Qurān in simple English

15. Monotheist Group: The Qurān: a monotheist translation

16. Qadri, T.: Irfan-ul-Quran

17. Sale, G. The Koran

18. Starkovsky, N.: The Koran handbook: an annotated translation

19. Tarazi's A: Allah's words in plain English

20. Yuksel, al-Shaiban and Schulte-Nafeh: A Reformist Translation of the Qurān

Saheeh International is used as a Control Version. The notion of control in the context of this article is different from the use of this term in experimental research design. Nevertheless, the function in both cases is analogous. It should be noted that the use of a 'control version' is a common practice in comparing translations of both the Scripture and the Qurān. For instance, Strauss (2008) uses it in comparing a dozen of Bible translations. As well, Robinson (2007) uses Pickthall's translation as the Control Version against which ideological and sectarian bias is analyzed in several translation of the Qurān. Similarly, Sideeg (2014) uses Saheeh International and three other translations as control versions for both qualitative and quantitative analyses in investigating sources of linguistic variations in translating the Qurān into English. The selection of Saheeh International here is based on some of the version's characteristic features. Saheeh International (2010) conforms to mainstream Muslim views, tends to be free from sectarian bias, and follows "English word order ... [that] conform[s] more closely to ... the Arabic text ... and the reader is brought somewhat closer to the feel of the original expression" (p. ii).

\section{Results: Presentation and Analysis}

\section{Case (1)}

The first case discussed in this article shows how complex traces of ideologies may combine to produce a radically alien reading of some Qurānic texts. The case discussed below is about one of the most recited verses in the Qurān. Analysis here basically focuses on how traces of ideology contribute to the 'gender-neutral' readings in translating the Qurān. 
Though most of the translations of this verse explored in this article abound in stylistic and discoursal variations of every type and betray some sort of ideological readings, Helminski's version goes too far in ideology-translation mapping to produce 'things unattempted yet in prose or rhyme.'

\section{Control Version}

Allah - there is no deity except Him, the EverLiving, the Sustainer of [all] existence. Neither drowsiness overtakes Him nor sleep. To Him belongs whatever is in the heavens and whatever is on the earth. Who is it that can intercede with Him except by His permission? He knows what is [presently] before them and what will be after them, and they encompass not a thing of His knowledge except for what He wills. His Kursi extends over the heavens and the earth, and their preservation tires Him not. And He is the Most High, the Most Great

\section{Helminski’s Version}

God- there is no deity but Hu, the Ever-Living, the SelfSubsisting Source of all Being. No slumber can seize Him/Her nor sleep. All things in heaven and on earth belong to $\mathrm{Hu}$. Who could intercede in His/Her Presence without His/Her permission? He/She knows what is what appears in front of and behind His/Her creatures. Nor can they encompass any knowledge of $\mathrm{Him} / \mathrm{Her}$ except what $\mathrm{He} / \mathrm{She}$ wills. His/Her throne extends over the heavens and the earth, and $\mathrm{He} / \mathrm{She}$ feels no fatigue in guarding and preserving them, for $\mathrm{He} / \mathrm{She}$ is the Highest and Most Exalted.

Helminski (2000), commenting on her peculiar use of the pronoun ' $\boldsymbol{H u}$ ' and the ' $\boldsymbol{H e} / \mathbf{S h e}$ ' combination in reference to Allah (SWT), maintains that

$H u$ : the pronoun of Divine Presence. All words in Arabic have a gender grammatically ascribed to them as they do in French and Spanish, etc. Although Allah is referred to with the third person masculine pronoun $\mathrm{Hu}$ $(H u w a)$, it is universally understood that Allah's Essence is beyond gender or indeed any qualification. In this translation occasionally $H u$ will be used and sometimes "He/She" in an attempt to avoid the mistake of attributing human gender to that which is beyond all our attempt at definition, limitless in subtle glory (p. 5).

Helminski is very clear on her ideological stance regarding 'gender-issues' and 'gender-neutral' language in translating the Qurān. In the preface to her translation she explains that

Regarding the use of pronouns [...] in some cases I have used the feminine pronoun rather than the masculine for both the human being and occasionally in reference to God so that those reading these selections may have a reminder that within the Universe and understanding of the Qurān, God is without gender... In God's sight men and women are equal. (Helminski, 2000, p. xiv)

Hence, Hassan's (2011) comment on Helminsk’s ideological reading is valid and significant:

Even though Helminski did not address the problem of transferring feminine imagery and nuances from Arabic into English, she consistently sought to adjust and soften the patriarchal tone in the target text by using inclusive nouns and pronouns to refer to human beings and to the Supreme Deity (p. 224).

Though Helminski's argument for using the combination $\mathbf{H e} / \mathrm{Sh} \boldsymbol{e}$ has the feminist agenda as a frame of reference, it is quite evident that her peculiar use of the pronoun ' $\boldsymbol{H} \boldsymbol{u}$ ' is essentially a Sufi choice reflecting her ideological and cultural background. The pronoun 'Hu' is widely used among the Sufis as the Greatest Name of Allah (SWT). In using the peculiar pronoun ' $\boldsymbol{H} \boldsymbol{u}$ ', it is obvious that Helminski's version is deeply rooted in the Sufi gnostic traditions. The pronoun 'Hu' is widely used among the Sufis as the Greatest Name of Allah (SWT). Produced by radical Sufi translators, Hulusi-Atalay's version prefers to use the pronoun 'Hu' in reference to Allah (SWT). In fact, in HulusiAtalay's version, Allah is defined by the pronoun or name 'HU'.

HulusiAtalay's Version
Allah is HU! There is no God (deity), only $\underline{\text { HU} ! ~ T h e ~ H a y y ~ a n d ~ t h e ~ Q a y y u m ~(t h e ~ s o l e ~ s o u r c e ~}$ of life and the One who forms all things in His Knowledge with the meanings of His Names - the One with whom everything subsists). Neither drowsiness overtakes Him (separation from the worlds even for a single instance) nor sleep (leaving creation to its own accord and withdrawing to His Self). To Him belongs everything in the heavens and on earth (the dimensions of knowledge and acts). Who can intercede in His sight except by the permission of the forces that manifest from the Names in one's essence? He knows the dimension in which they live and the dimension they are unable to perceive... Nothing of His knowledge can be grasped if He does not will (allow via the suitability of the Names in one's essence). His throne (sovereignty and administration [Rububiyyah]) encompasses the heavens and the earth. It is not difficult for Him to preserve them. He is the Aliy (illimitably supreme) and the Azim (possessor of infinite might). 
Hulusi-Atalay's version above discloses the radical gnostic ideology that underpins their translation. The use of 'HU' is the essence of the Sufi conception:

HU is the inner essence of the reality of everything that is perceived... To such extent that, as the reflection of Akbariyyah, first awe then nothingness is experienced and, as such, the Reality of Hu can never be attained! Sight cannot reach HU! HU denotes absolute obscurity and incomprehension! As a matter of fact, all names, including Allah are mentioned in connection with HU in the Qurān! (Hulusi and Atalay, 2013, p. 31).

Moreover, in Hulusi-Atalay's ideological reading the concept of the Sufi Pantheism or Unity of Being is consciously injected into the Qurānic discourse. The re-interpretations and expansions (The Hayy and the Qayyum (the sole source of life and the One who forms all things in His Knowledge with the meanings of His Names-the One with whom everything subsists)) reveals the essence of Hulusi-Atalay's doctrine.

Yet, the question is that why doesn't Hulusi-Atalay's version use the combination $\boldsymbol{H e} / \mathbf{S h} \boldsymbol{e}$ as Helminiski's version does? After all, the two versions draw on the same philosophical doctrines and cultural background. The answer lies in the fact that Hulusi-Atalay's version embraces a more radical gnostic reading to the extent that the concept of the Divine itself becomes an illusionary symbol, never affected by the superficial use of language. In the preface to the translation of Hulusi-Atalay's version from Turkish to English, Atalay maintains that though "the masculine pronoun ' $\boldsymbol{H} \boldsymbol{e}$ ' was unavoidable, it is needless to say 'Allah' - the infinite consciousness beyond all preconceived and preconditioned ideas - transcendentally and indubitably surpasses any gender or form." Yet, this statement is equivocal, for the argument for this "unavoidable" use of the masculine pronoun " $\boldsymbol{H e}$ " in reference to Allah (SWT) is not based on the linguistic facts of both SL and TL, but rather on an alien philosophical and gnostic conception of the Divine. Atalay maintains that it is "important to keep in mind that 'Allah' is a name that encompasses all the Names, qualities and attributes - the manifest and the unmanifest - pertaining to existence and nonexistence" (Hulusi and Atalay, 2013, p. ii).

As well, Helminski's use of the combination $\mathbf{H e} / \mathbf{S h e}$ in reference to the Divine echoes an extreme esoteric reading that several Sufi philosophers and poets opt to address the Divine as a 'female deity'. Many a scholar observes that addressing a 'feminine God' is a common tradition in the Sufi literature. Galian (2004) notes that 'it has been gathered that Allah is, as defined by numerous Sûfîs, the feminine form of the ultimate reality." Rumi, one of the most famous Sufi philosopher poets and Helminski's spiritual guide, is one of the numerous figures who embrace this notion. "Keshavarz, talks most poetically of the gendered nature of the images and metaphors through which Rumi portrayed the sacred. He chose womanhood, the ability to nurture, and the privilege of childbearing as metaphors for the sacred," (Jaffer, 2007). Rumi's philosophy postulates that woman is the most sublime example of Allah's creative power on earth. In 'Spiritual Couplets', his monumental literary work, Rumi writes:

\section{Woman is the radiance of God, she is not your beloved. She is the Creator-you could say that she is not created.}

Nicholson (2002, I:2437).

Rumi's lines represent one of the clearest statements about the Divine or Scared Feminine in the Sufi literature that elevate woman to a state of a divine being, making her an equal entity to the Divine Essence. Still, this Sufi doctrine finds its clearest expression in Ibn 'Arabi's writings. In Ibn 'Arabi's philosophy, the male and female elements are coupled in a symbolic gnostic unity, paving the way for his theory of Sufi Pantheism or Unity of Being. (ابن عري،، 2003)

Commenting on Ibn 'Arabi's doctrines of the sacred feminine, Ahmed (2014), a Sufi blogger, writes

The Tarjumân al-ashwâq, Ibn al-'Arabî's collection of love poems composed after meeting the learned and beautiful Persian woman Nizam in Mecca, is filled with images pointing to the Divine Feminine. The last chapter in his book Fusûs al-hikam relates that man's supreme witnessing of Allah is in the form of the woman during the act of sexual union. The contemplation of Allah in woman is the highest form of contemplation possible:

As the Divine Reality is inaccessible in respect of the Essence, and there is contemplation only in a substance, the contemplation of God in women is the most intense and the most perfect; and the union which is the most intense (in the sensible order, which serves as support for this contemplation) is the conjugal act.

The centrality of the Divine or Sacred Feminine in the Sufi schema then pinpoints a significant possible source of Helminski's rather unusual version which uses the masculine/feminine pronouns in translating one of the most awesome verses that describe Allah's (SWT) attributes in the Qurān. This choice, which Helminski repeatedly and consistently employs in her version, demonstrates the strong and significant effect of her Sufi background and ideology in shaping the linguistic content in translating the Qurān in a way that no other factor can do. Galian (2004) argues that in Ibn Arabi's schemata Allah (SWT) is both masculine and feminine divine entity as he once stated "I sometimes employ the feminine pronoun in addressing Allah, keeping in view the Essence". Galian notices that in his writings, Ibn Arabi repeatedly talks about the "abysmal Darkness" and "the ultimate ground of everything is the Mother (umm)". Ibn Arabi believes that Allah (SWT) can be referred to as both "huwa" (He) and "hiya" (She). This is exactly what Helminski adopts in her version of the Qurān in English. 


\section{Case (2)}

If Helminsk's version changes the system of pronouns in this Qurānic text on the basis of feminist and Sufi perspectives, Tarazi's version, which lies at the extreme end of dynamic equivalence pole in translating the Qurān, (Sideeg, 2014), changes the pronoun system on the basis of hermeneutical readings. Its author claims that he translates "Allah's word in plain English". Tarazi (2012) explains his approach as follows:

This style of translation is called dynamic equivalence translation. To the extent possible, this approach seeks to create an experience in plain English which communicates both the ideas and the emotions the Qurān communicated to the original audience in classical Arabic. All translations necessarily involve many compromises between ideas and emotions, sophisticated layered meaning, and simplicity. It is our hope that this translation will provide the average English speaking audience at least a balanced taste of the beauty and power of the Qurān in plain English.

Nonetheless, it seems here that 'dynamic equivalence' is only a disguise for some sort of ideological agenda: the changes done in translating the case discussed here are more than stylistic or purely linguistic issues. A comparison between Tarazi's version and Kidwai's version [another translation that uses simple English] reveals this fact.

\section{Kidwai's Version}

God is the Ever Living, the Self Subsisting. There is no god beside Him. Neither slumber nor sleep overtakes Him. He is all that in heaven and all that on earth. Who can recommend (anyone's case) to Him, except with His permission? He knows what lies before and behind His creatures. They cannot encompass anything of His knowledge except what he wills. His throne extends over the heavens and the earth. He is All High, Most Glorious.

\section{Tarazi's Version}

I am your true God the one and only. I live eternally. I oversee and take care of everything. I never tire, and I am never sleeping. Who can intercede in front of Me without my authorization? I know the future and the past, and you don't acquire any of my knowledge without my permission. My knowledge encompasses the earth and the heavens. It is not difficult for Me to take care of everything in both of them. I am high in power and greatness over everyone and everything.

The most notable change in Tarazi's version is the drastic alteration of the third person pronoun system and the shift to first person pronouns. Thomas (2002) acknowledges the fact that there is a considerable amount of hermeneutics in a dynamic-equivalence translation. Undoubtedly, this makes a translation based on this approach an ideal haven for injecting traces of ideological readings. This is exactly the case of Tarazi's version. Avoiding what he thinks a sexist language that uses the masculine pronouns 'he, him, his, etc.' in reference to Allah (SWT), Tarazi, as shown in the sample above, replaces third person pronouns in reference to Allah (SWT) with first person pronouns, and thus destroys both the distinctive texture and structure that significantly contribute to the of unique fusion of structure and meaning in the Qurānic discourse.

Case (3)

Though precise and direct, the verses presented in the third case clearly show how ideology may sometimes supersede every other concern in the process of translating the Qurān. Even though there are many stylistic variations and ideological readings in translating these verses, there is one unequivocal case that shows how purely ideological concerns produce unparalleled and unmatched interpretations that amounts to some sort of blatant distortion.

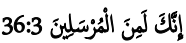

\section{Control Version Indeed you, [O Muhammad], are from among the messengers,}

Control Version's bracketed phrase [O Muhammad] is superfluous as the contextual clues are crystal clear on the identity of the addressee. Yet, some versions adopt methods of interpretation and expansion, with Haque-Khan's version betraying some sort of ideological stance. The enhancement of the status of the Prophet (PBUH) goes beyond the SL text, exposing the translator's Sufi background. Further, Dawood's version is not unequivocally free from ideological bias.

Asad, M

Abdel Haleem, M.S.

Dawood, N. J

Bakhtiar, L

Qadri, T.

Haque and Khan verily, thou art indeed one of God's message-bearers, you [Muhammad] are truly one of the messengers sent

that you are sent

truly, thou art among the ones who are sent

You are indeed one of the Messengers,

You (O dear Prophet Mohammed - peace and blessings be upon him) are indeed one of the Noble Messengers. 
Nevertheless, nothing could match Rashad Khalifa's weird translation in his ‘authorized version':

Khalifa, R. $\quad$ Most assuredly, you (Rashad) are one of the messengers.

Writing down his own gnostic ideology rather than translating the Qurān, in this case Khalifa himself replaces the Prophet (PBUH) as the addressee. This is something Khalifa does in two other verses:

Khalifa, R.

We have sent you (Rashad) as a deliverer of good news, as well as a warner.

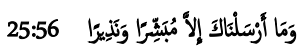

Khalifa, R.

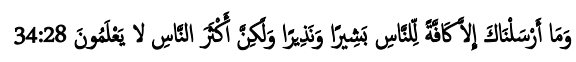

We have sent you (O Rashad) to all the people, a bearer of good news, as well as a warner, but most people do not know.

Here translation is purely an ideological act as the linguistic facts of the SL text are totally discarded. A basic tenet of Khalifa's ideological schemata is the claim that he is the final messenger (rasool) ", and that the Archangel Gabriel 'most assertively' told him that this Qurānic verse 'specifically' refers to him. For Khalifa (2005) “'Nabi' is a messenger of God who delivers a new scripture, while 'Rasoul' is a messenger commissioned by God to confirm scripture; he does not bring a new scripture" (p.628). Thus, Khalifa believes that "Muhammad was the last prophet (Nabi), but not the last (Rasoul)," and the whole argument is based on his 'number 19-theory':

This crucial definition is confirmed by the Qurān's mathematical code. The expression used in 33:40, "Muhammad Khaatum Al-Nabiyyeen" (the last prophet) has a gematrical value of 1349, 19x71, while the value of the erroneous expression "Muhammad Khaatum Al-Mursaleen" (the last messenger) is not a multiple of 19 (Khalifa, 2010, p. 518).

Khalifa is central to the founding of the United Submitters International (USI), an offshoot group that usually prefers not to use the terms Muslims or Islam, and instead they use the English terms 'Submitters' and 'Submission'." Moreover, Khalifa is a staunch Qurānist who vehemently rejects Hadith and Sunna as falsehood and fabrications. For him Hadith and Sunna are Satanic innovations and fabrications. Khalifa, thus, has his own schema for understanding the Qurān. A corner stone of this schema is the claim that the Qurān contains a mathematical miraculous structure based on the number 19, which leads him to claim that the last two verses of the ninth Sura of the Qurān are not canonical and should thus be discarded from the Divine Revelation. Khalfia believes that his version of the Qurān is authorized, not in the sense King James Bible was authorized by the King, but rather, Khalifa claims that his translation is authorized by God himself.

Case (4)

This case concerns the translation of reference of some personal pronouns in a SL text that is highly condensed and stylistically complex:

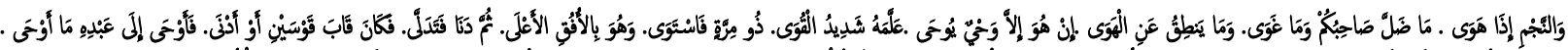

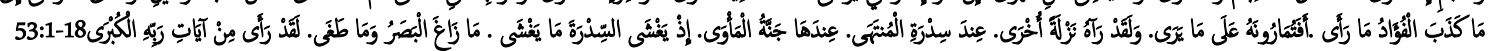

Control Version By the star when it descends, Your companion [Muhammad] has not strayed, nor has he erred, Nor does he speak from [his own] inclination. It is not but a revelation revealed, Taught to him by one intense in strength - One of soundness. And he rose to [his] true form While he was in the higher [part of the] horizon. Then he approached and descended. And was at a distance of two bow lengths or nearer. And he revealed to His Servant what he revealed. The heart did not lie [about] what it saw. So will you dispute with him over what he saw? And he certainly saw him in another descent. At the Lote Tree of the Utmost Boundary Near it is the Garden of Refuge - When there covered the Lote Tree that which covered [it]. The sight [of the Prophet] did not swerve, nor did it transgress [its limit]. He certainly saw of the greatest signs of his Lord.

Almost all the versions investigated in this article echo the Control Version which is essentially a literal and faithful copy of the SL text. For instance, Starvosky's version runs as follows:

$1 *$ [I swear] by the star when it sets!

2* Your companion did not lose his way and did not go astray!

3. He does not speak for himself,

4. but reveals the inspiration that inspired him.

$5 *$ He was taught by someone great in power,

6. full of wisdom, who stood upright

7. in the highest horizon.

8. Then he descended and approached

9. within two bow shots or nearer,

$10^{*}$ and inspired to His servant what He inspired.

11. His heart did not deceive him about what he saw! 
12.So, why do you argue with him about his vision?

13* He saw [the Spirit] at the second descent

$14 *$ by the farthest Sidrah-tree

15* near the Garden of Salvation,

16. by the Sidrah-tree enshrouded in what enshrouded it.

17.His eyes neither strayed nor faltered.

18.Verily, he saw the greatest Sign of his Lord!

Though ideologically-motivated, it should be noted here that Asad's version removes any kind of ambiguity with regard to references of the repeated pronoun [he] in the relevant text by bracketed additions:

Asad, M CONSIDER this unfolding [of God's message], as it comes down from on high! This fellow-man of yours has not gone astray, nor is he deluded, and neither does he speak out of his own desire: that [which he conveys to you] is but [a divine] inspiration with which he is being inspired something that a very mighty one has imparted to him: [an angel] endowed with surpassing power, who in time manifested himself in his true shape and nature, appearing in the horizon's loftiest part, and then drew near, and came close, until he was but two bow-lengths away, or even nearer. And thus did [God] reveal unto His servant whatever He deemed right to reveal. The [servant's] heart did not give the lie to what he saw: will you, then, contend with him as to what he saw? And, indeed, he saw him a second time by the lote-tree of the farthest limit, near unto the garden of promise. with the lote-tree veiled in a veil of nameless splendor.... [And withal,] the eye did not waver, nor yet did it stray: truly did he see some of the most profound of his Sustainer's symbols.

Nonetheless, there are two versions which present a different scenario that reflects the ideological and sectarian readings adopted by their authors. Both Qadri's and Haque-Khan's versions interpret the 'star' as being the Prophet Muhammed (PBUH) without any linguistic or contextual clue. On the contrary, the SL text in using the verb (هَ'ى) makes impossible to give this verse this allegorical interpretation used by both these authors. This enhancement of the status of the Prophet Muhammad (PBUH) is a characteristic feature of both versions due to the Sufi (Barelwi) background of both (Robinson, 2007, p. 263). This enhancement of the status of the Prophet (PBUH) leads to the second instance of the two versions' radical departure from Control Version and almost all translations of the Qurān in English, is the invariant use of the pronouns $\mathrm{He} / \mathrm{His}$ in reference to Allah (SWT) in all instances in this text.

Qadri's By the bright star (Muhammad [blessings and peace be upon him]) when (he ascended Version during the Ascension Night in the twinkling of an eye and) descended. He who bestowed on you his companionship (i.e., the Messenger, who made you his companions by blessing you with his companionship,) has never lost his way, nor has he (ever) strayed from the right path. And he does not speak out of his (own) desire. His speech is nothing but Revelation, which is sent to him. (The Lord) of Mighty Powers (directly) conferred on him (perfect) knowledge, He Who is absolute beauty. Then He (the Effulgence of Beauty) decided to unveil (Himself). And he (Muhammad [blessings and peace be upon him]) was on the uppermost horizon (of the realm of creation during the Ascension Night i.e., on the apex of the created cosmos). Then He (the Lord of Honour) drew closer (to His Beloved Muhammad [blessings and peace be upon him]) and then drew even closer. Then a distance measuring only two bow-lengths was left (between Allah Unveiled and His Esteemed Beloved), or even less than that (in extreme nearness). So (on that station of nearness) He (Allah) revealed to His (Beloved) servant whatever He revealed. (His) heart did not take it contrary to what (his) eyes beheld. Do you argue with him about what he saw? And assuredly, he saw Him (Allah Unveiled) the second time (again and you argue only about seeing Him once). At the farthest Lote-Tree-Sidra al-Muntaha, Adjacent to that is the Eternal Paradise-Janna alMa'wa, When theophanies (i.e., effulgent disclosures) of the divine light wrapped up alSidra (the Lote-Tree at the Far End), covering it expansively. His eye neither inclined aside nor overstepped the limit; (it gazed in ecstasy at Whom it was to gaze). Surely, he saw the greatest signs of His Lord (during the Ascension Night).

Haque and By oath of the beloved shining star Mohammed (peace and blessings be upon him), when he Khan's returned from the Ascent. Your companion did not err, nor did he go astray. And he does Version not say anything by his own desire. It is but a divine revelation, which is revealed to him. He has been taught by the Extremely Powerful. The Strong; then the Spectacle inclined towards him. And he was on the horizon of the highest heaven. Then the Spectacle became closer, and came down in full view. So the distance between the Spectacle and the beloved was only two arms' length, or even less. (The Heavenly Journey of Prophet Mohammed - peace and blessings be upon him - was with body and soul.) So Allah divinely revealed to His bondman, whatever He divinely revealed. The heart did not deny, what it saw. (The Holy Prophet was bestowed with seeing Allah) What! So do you dispute with him regarding what 
he saw? And indeed he did see the Spectacle again. Near the lote-tree of the last boundary. Close to which is the Everlasting Paradise. When the lote-tree was being enveloped, by whatever around it. The sight did not shift, nor did it cross the limits. Indeed he saw the supreme signs of his Lord.

The ideological reading of both versions involves the use of far-fetched interpretations and additions/reference to Allah (SWT) through all the narration without any reference to the Archangel Gibreel and invariable use of pronouns He/His with reference to Allah (SWT).

Case (5)

The fifth case reflects the impact of the neo-Mu'atizilte and pseudo-scientific thoughts on interpreting and translating the Qurān.

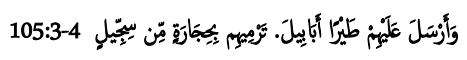

Control Version And He sent against them birds in flocks, Striking them with stones of hard clay,

Ali, A And sent hordes of chargers flying against them, (While) you were pelting them with stones of porphyritic lava,

Ahmed, s. $\quad$ And sent upon them swarms of flying creatures. Then you showered them with hard stones earmarked with requital. ('Sijjil' = Inscribed = Marked out).

Both Ali's and Ahmed's version switch the act of destroying the invading army from 'birds' to 'men', creating a drastically different interpretation that the original Qurānic text never accommodates.

Case (6)

The last case explored in the present article is a verse that states the role of the Prophet (PBUH) in explaining the Qurān:

Control Version And We revealed to you the message that you may make clear to the people what was sent down to them and $t$

at they might give thought.

Control Version echoes most versions investigated which translate explain, may make clear, may explain, make clear; etc.,

Sale, G. and We have sent down unto thee this Koran, that thou mayest declare unto mankind that which hath been sent down unto them, and that they may consider.

Asad, M. And upon thee [too] have We bestowed from on high this reminder, so that thou might make clear unto mankind all that has ever been thus bestowed upon them, and that they might take thought.

Qadri, T. We have revealed to you the Glorious Reminder (the Qur'an) so that you may explain clearly to people (the message and the commandments) that have been sent down to them and that they may meditate.

Haque and Khan and We have sent down this Remembrance towards you (O dear Prophet Mohammed - peace and blessings be upon him) so that you may explain to mankind what has been revealed towards them, and that they may ponder.

Dawood's and Bakhtiar's versions seem to be ambiguous:

Dawood, N. J

To you We have revealed the Admonition, so that you may proclaim to men what was sent down for them, and that they may take thought.

Bakhtiar, L

We caused to descend the Remembrance to thee that thou wilt make manifest to humanity what was sent down to them and so that perhaps they will reflect.

However, Bewley-Bewley's and Abdel Haleem's versions contain a significant variation:

Bewley and Bewley And We have sent down the Reminder to you so that you can make clear to mankind what has been sent down to them so that hopefully they will reflect.

Abdel Haleem, M. We have sent down the message to you too [Prophet], so that you can explain to S. 
In Bewley-Bewley's and Abdel Haleem's versions, the use of the modal 'can' rather than 'may' along with the phrase 'make clear' has some ideological significance. It indicates a firm belief that the Prophet (PBUH) is the one who is able to explain the meanings of the Qurān. However, it is not obvious whether most of the translators of the Qurān were aware of the mild nature of the modal 'may' or they were just copying Sale's version which has had strong but often unacknowledged influence on most of the subsequent translations of the Qurān.

Yet, Ahmed's, Khalifa's, Monotheist, and Reformist versions of this verse are ideologically motivated by the belief that the Qurān must be separated from the Prophet (PBUH), and thus interpreted and understood independently with no reference to the Sunna or Hadith.
Khalifa, R.
And we sent down to you this message, to proclaim for the people everything that is sent down to them, perhaps they will reflect.

\section{Monotheist Trans. And We sent down to you the Reminder to reveal to the people what was sent to them, and perhaps they will think.}

Reformist Trans. We sent down to you the Reminder to proclaim to the people what was sent to them and perhaps they would think.

Ahmed, S.

And now, (O Prophet) We have revealed this Reminder to you so that you convey to mankind what has been revealed for them. So that they may think.

\subsection{Discussion: A Critique of the Results of the Six Cases Explored}

\section{Case (1)}

Analysis of case (1) exposes the ideological traces involved in Helminski's 'unorthodox' reading with regard to the use of what she thinks a 'gender-neutral' language in reference to Allah (SWT). However, there is a serious flaw in Helminski's logic and arguments. In using the feminine and masculine pronouns in reference to Allah (SWT), Helminski fails to appreciate the wide distinction between grammatical and natural gender, a distinction that undermines all arguments about gender-issues in translating the Qurān. In fact, the question of natural vs. grammatical gender is subtle and intricate. Grammatical genders are a special type of noun classes where gender is reflected in the structure of the word. Yet, this distinction between natural and grammatical gender does not exist in Modern English because words are only grammatically masculine or feminine if they are correspondingly naturally masculine or feminine. When a word does not have a natural gender-like the word 'door', for example - it is grammatically neuter and one refers to it with the neuter pronoun, 'it', not the masculine pronoun "he", or the feminine pronoun "she". But generally, in languages that have grammatical genders (Arabic is one of them), the most significant fact is that these grammatical genders are arbitrary. Here it should be remembered that the etymology of the word 'gender' has nothing to do with biological 'sex' as the term is etymologically related to the term 'genre'. Oxford Shorter Dictionary ( $6^{\text {th }}$ edition), tells us that the origin of the word is Old French gendre (mod. genre) from Proto-Romance from Latin genus, gener.(Shorter Oxford English Dictionary, 2007, p. 1088).

A basic linguistic fact is that when feminine and masculine noun classes exist in language, they mean virtually nothing from a non-linguistic point of view, as a word's grammatical gender is arbitrary and does not logically correlate with its meaning. So there may not be a correspondence or association between a given word's natural and grammatical genders (Lyons, 1995, pp., 283- 285). This is reflected by the fact that gender does not transfer well from one language to another. For instance, the word for 'sun' is masculine in Spanish (el sol) but feminine in German (die Sonne). A German moon is masculine (der Mond), while a Spanish moon is feminine (la luna). By the same token, the word 'porte' (French for 'door') is grammatically feminine and one refers to it with the same pronoun used for "Mary" or "Fatima", i.e., elle (French for "she"). The Arabic word (باب) (Arabic for "door"), however, is grammatically masculine, so one refers to it with the same pronoun that one uses for "Ali" or "John", i.e., huwa (Arabic for "he"). And while many of the world languages have nouns that are either masculine or feminine, German, for example, adds a third gender: neuter. Moreover, German is a good example of the fact that gender is not linked to a specific meaning or concept. Although nouns denoting human beings are expected to follow natural gender, in German there are exceptions such as das Mädchen, (girl). Plus, there are three different German words for "ocean" or "sea"-all a different gender: der Ozean (Masculine), das Meer (Neutral), and die See (Feminine).

All this discussion points to the fact that the presence of a neuter gender for all nouns which are neither masculine nor feminine in English and its absence in Arabic (and many languages), causes significant linguistic mismatch. A consequence of this mismatch is that in English, if one uses the masculine or feminine pronouns to refer to something that has no natural gender, one is representing the thing as a person, usually for powerful rhetorical effect. This is called 'personification', a rhetorical device often used in poetry. In languages like Arabic or French, masculine or feminine pronominal references carry no such connotations. Grammatical gender, as already stated, is entirely based on language conventions.

Badran, cited in Hidayatullah (2014), observes that "English is a common language of Islamic feminism" (p. 6). It is a fact that feminist ideological readings, particularly Helminski's use of He/She combination, is born in predominantly Christian and English language speaking cultures, where the use of the pronoun "He" confirms the male God of the Trinity, 'God the Father' in the Christian schema. Modern feminist arguments for gender-neutral references to God are essentially reactions to the masculine portrayal of God in Christianity. Using this kind of discourse in the Qurānic 
context and raising gender-issues in reference to Allah (SWT) in the way feminists have done in the tradition of Bible translation would miss several linguistic and cultural facts and contradicts the clear Qurānic statement with reference to

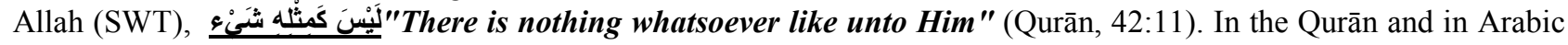
language, Allah (SWT) is referred to by the masculine pronoun 'huwa' without any explicit or implicit sense of personification or anthropomorphism. It is only a linguistic fact that the word "Allah" is grammatically masculine in Arabic, with no hint or connotation of natural gender or any other human attributes. The basic pillar of the Islamic belief is that Allah (SWT) cannot be understood in human terms of natural genders (masculine and feminine). It is the anthropomorphic conception of Allah (SWT) that makes anybody think of $\boldsymbol{H e}$ She distinction in reference to the Divine. Whereas many religious texts suffer the curse of 'personification' or 'anthropomorphism', where the use of a masculine pronoun reference denotes or connotes masculinity of the Divine, the transcendent cornerstone of Islamic tawheed does not allow any kind of 'anthropomorphism' or personification that ascribes any human qualities or attributes to Allah (SWT). Ibn Arabi, Rumi, and Helminski's use of feminine terms with reference to Allah (SWT) is entirely alien to the Islamic belief in which Allah (SWT) is transcendent beyond human concepts, terms, and distinctions.

To sum up, all this discussion clearly points out to the relevance of the Sufi philosophy of the Divine Feminine in Helminski's peculiar ideological reading. Madigan (1998) observes that

Woman reveals for Ibn 'Arabi the secret of the compassionate God. The word for essence, dhat, being feminine in Arabic offered Ibn 'Arabi different methods to discover this feminine element in God and meant that he could speak of the "woman creator". His contemporary, the Egyptian poet Ibn al-Farid used the feminine gender in his mystical odes when talking of the divine beloved.

Magdian's statements explicitly reveal how the notion of the Divine/Scared Feminine strongly shapes many Sufi philosopher-poets, inspiring them to address a feminine God. This significantly further enhances the explanation of Helminski's reading which produces a version unsurpassed except by very few versions in the tradition of Bible translation, versions which Poythress and Grudem (2000) exclude in their thesis on 'The Gender-Neutral Bible Controversy' on the basis that these handful of "radical feminist versions that even undertake to call God the Father "Father and Mother" or to eliminate "Father" language altogether. ... clearly reject the authority of the Bible and its claim to be the Word of God..." (p. 25). Even deWaard and Nida (1986), two of the prominent figures advocating the dynamic equivalence approach in Bible translation, aptly call the works of extreme feminist Bible translators who introduce radically inclusive language in translating the Scripture "an almost incredible distortion" (pp. 24-25). Nevertheless, Helminski's case is dual: fueled by the Sufi traditions of Rumi, Ibn 'Arabi, and an avowed and sincere exponent of gender equality, her version remains the most radical one regarding 'gender-neutral' language in reference to the Divine among all the translations of the Qurān in English.

Case (2)

Tarazi's argument for simplification of the Qurānic text through using the first person pronoun ' $\boldsymbol{I}$ ' instead of the third person pronoun ' $\boldsymbol{H} \boldsymbol{e}$ ' is not valid as it is not based on the ontological nature and stylistic facts of the SL text. This type of 'simplification' seems to be ideologically motivated as the author attempts to abolish the SL pronoun system which is seen as 'patriarchal' or 'sexist'. However, when we mess with the SL original system of pronouns, we obscure the content of the Qurānic message and make it more difficult to appreciate and understand significant stylistic and discoursal aspects which are part and parcel of the Qurānic text. The purposeful variation in the stylistic and discoursal features of the Qurān is observed by Az-Rakashi who states that one of mechanism of the Qurānic stylistics is 'Iltifät' which is:

"الانتال من أسلوب إلى آخر لما في ذلك من تنشيط السامع واستجلاب صفاثه واتساع بجاري الكلام وتسهيل الوزن والقافية. وقال البيانيون: إن الكلام إذا جاء على أسلوب واحد وطال حسن تغيير الطريقة " (الزركثي، (1984، ص 326-325).

Transition from one mode to another as it serves to help the listener focus on the message and avoid boredom, renew their interest, make speech flow more smoothly, and refine rhyme, rhythm and cadence in the speech. Rhetoricians recommend variations of style and discourse in lengthy and uniform texts.

Drawing on this, Abdel Haleem (1992) aptly observes that

The Qur'ān, it should be remembered, is not an autobiography of Allāh which thus has to be cast wholly in the form of 'I' and 'me'; ... It should also be noted that in some verses God is mentioned more than once, and is depicted from different perspectives so that we have a multiplicity of viewpoints (p. 417).

The Qurān is a literary masterpiece with its own unique stylistic and discoursal legacy. The use of pronouns (We, I, He) for Allah (SWT) in the Qurān is often a source of rich and distinctive discoursal and stylistic dimensions and meanings. Use of 'I' for Allah (SWT) in the Qurānic discourse normally occurs on occasions when His oneness or closeness to the addressee is targeted or focused. When the pronoun 'We' is used in reference to Allah (SWT), it is meant to emphasize the grandeur, power, strength, and the infiniteness of His attributes. 'He' is used in the Qurān to refer to Allah (SWT) from the perspective of the addressee. This is why Traza fails to consistently and thoroughly alter the use of 'He' in reference to Allah (SWT) in the context cited below: 


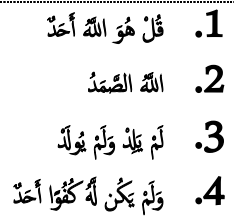

(112:1) If they ask you about Me, say: He is the one and only.

(112:2) Allah, the only one to turn to for help.

(112:3) He has no child, nor was born from a parent,

(112:4) and He is not like anything else.

\section{Case (3)}

One issue that Khalifa's 'number 19-theory' fails to explain is the fact that the Qurānic verses (36:3) and (25:56) presuppose the existence of "you" at the time of their revelation. This existential presupposition would deem the 'number 19-theory' null and void since the 'myth' never addresses this core question: whom did Allah (SWT) address in this verse before Khalifa's birth? One has to have highly exotic imagination to perceive the claim that Allah (SWT) addressed Khalifa with these verses hundreds of years ago before his coming to this world or to go so far to claim that Khalifa has always been there, a divine figure as Jesus Christ in the Christian schemata. Plus, why has Khalifa identified only himself as the messenger addressed in this verse? Perhaps there might have been thousands of people who had the same name (Rashad) before him, and certainly there would be many after him in this world.

Though this claim is linguistically and contextually baseless, it has repeatedly been documented and published in Khalifa's and his disciples' books and online articles. Khalifa believes that he himself is the most important messenger and his mathematical miracle the most significant phenomenon in the history of religions, much more significant than all the miracles given to Musa, Issa, and all the messengers combined.

Nonetheless, feeling the absurdity of his claim, Khalifa (2010), in "Appendix 2" of his 'authorized version' tries to give himself a mystic and spiritual glamor in order to justify the gnostic reading he adopts in rendering the relevant verses:

During my Hajj pilgrimage to Mecca, and before sunrise on Tuesday, Zul-Hijjah 3, 1391, December 21, 1971, I, Rashad Khalifa, the soul, the real person, not the body, was taken to some place in the universe where I was introduced to all the prophets as God's Messenger of the Covenant. I was not informed of the details and true significance of this event until Ramadan 1408 (p. 518).

Khalifa then narrates the details of his claimed encounter with Allah's Messengers (PBUT). How strange and ironic that Khalifa uses the story of the Prophet's (PBUH) night journey and ascension (Israa and Mi'rāj) despite his claim that all Hadiths are "Satanic innovations" (Khalifa, 2010, p. 713) and fabrications aimed at diverting people from the path of God (Khalifa, 2010, p.555). This, however, shows the strong gnostic factor in Khalifa's schema and explains the peculiar and alien readings in his authorized version, of which the case discussed here is the most bizarre and removed from the linguistic and contextual facts of the SL text.

\section{Case (4)}

Robinson (2007) has a detailed commentary on the Barlawi version of Kanzul Iman which was translated to English by Haque. He explains the Barlawi Sufi background of this version of the Qurān which focuses on the "enhanced status" of the Prophet (PBUH) and the special significance of the event of m'iraj and the fact that knowledge of the unseen is bestowed on the Prophet at that night. Robinson's comments apply to Qadri's version as well as other similar Sufi translations.

The question whether the Prophet (PBUH) saw Allah (SWT) or not is discussed by Ibn Tayyimia in the light of the narrations and traditions from the early generations of Muslims:

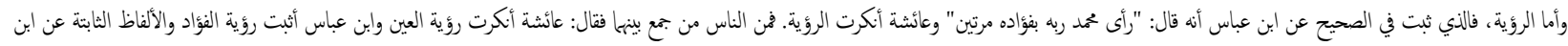

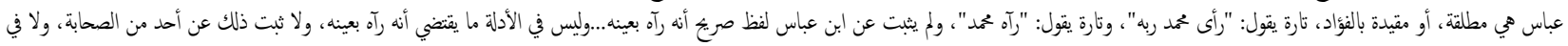

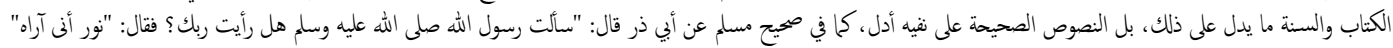

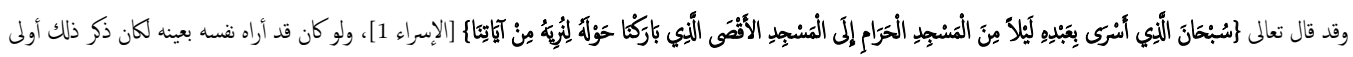

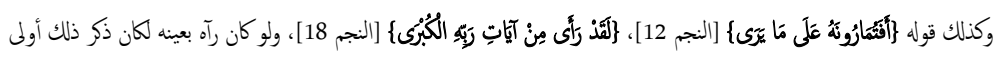

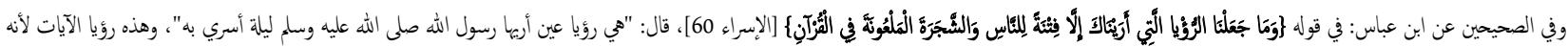

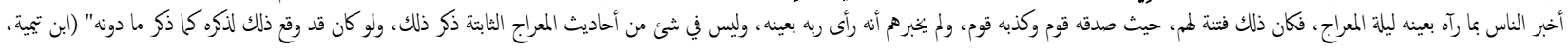

$$
\begin{aligned}
& 2004 \text { جزء 6, 509-510). }
\end{aligned}
$$

As for seeing Allah (SWT), the authentic narration from Ibn 'Abbas is that he said "The Prophet Muhammad saw Allah twice in his heart twice”, whereas 'Aisha denied it. Some scholars reconciled Ibn 'Abbas's and 'Aisha's point of views stating that 'Aisha denied the eye vision and Ibn 'Abbas confirmed seeing in the heart. The authentic narrations from Ibn 'Abbas are somehow undefined, or restricted to seeing in the heart. He on one instance said "Muhammad saw his Lord", on another 'Muhammad saw him'. No authentic report fr'Ibn Abbas contains the phrase that the Prophet saw 
Allah with his own eyes. Plus, there is no evidence in all authentic narrations from the Prophet's companions and the Qurān and Sunnah supporting that. On the contrary, authentic weighty narrations tell the opposite. As narrated in Saheeh Muslim by Abu Dhar saying: "I asked Allah's Messenger (PBUH) 'Did you see your Lord? 'How can I see Him since there was a light)" In another narration, the Prophet said."

Allah (SWT) says [Exalted is He who took His Servant by night from al-Masjid al-Haram to al-Masjid al- Aqsa, whose surroundings We have blessed, to show him of Our signs. Indeed, He is the All-Hearing, the All-Seeing.] Had Allah (SWT) shown His Own Self to the Prophet (PBUH), He would have narrated that most significant event in the Qurān.

In the two Saheehs, it is narrated that Ibn 'Abbas, commenting on the relevant verse, said, "It is what Allah's Messenger saw in the Night of Israa and M'iraj". It is about the vision, signs and miracles in that night, which was a trail for them. Some of them believed it, whereas some denied it. However, he did not tell them that he saw Allah (SWT) with his eyes. All narrations on the Prophet's Ascension do not mention this event. Had it happened, the Prophet would have mentioned it.

The claim that the Prophet (PBUH) saw Allah (SWT) with his own eyes is quite feeble and entirely unfounded on both the textual and logical levels. Had the Prophet Muhammad (PBUH) seen Allah (SWT), this would have been the most significant event in the timeline of Islam and the greatest cosmic event which would not be narrated only in short, controversial, and ambiguous texts.

\title{
Case (5)
}

In the fifth case, the question is why these versions switch the act of destroying the invading army from 'birds' to 'men', creating a drastically different version from almost all the versions of the Qurān available in English. After all, in the SL text, there is no linguistic clue in the SL text that might allow this kind of peculiar interpretation. Ahmed (2006) claims that

as Abrahah's army approached Makkah, the Makkans who had been alerted by some travelers beforehand, saw flocks of birds that normally fly over caravans in search for food. The Makkans mounted the hills around and threw stones on the troops. The elephants, and in turn, other rides panicked and trampled the soldiers (p. 10).

This is a byword of what a fictional scenario is in translating the Qurān. It shows that ideology may sometimes result in deliberate distortion that pays no attention to all historical, linguistic, and contextual aspects of the SL text. In the narratives and exegetes on relevant incident there is no hint of this fictional scenario adopted by Shabbir Ahmed and Ahmed Ali in translating the relevant verses.

Case (6)

For the Qurānists, the Hadith and Sunna of the Prophet (PBUH) are not more reliable or valid than the Scripture. Ahmad and Ali (1997), two of the leading submitters and disciples of Khalifa, claim that resources other than the Qurān "including previous scriptures as well the hadith/sunna, are subject to Qurānic criticism. What passes this criticism is acceptable; what fails is automatically rejected" (p.24). Ahmed (2007) believes that Bukari and other Narrators of Hadith are virtually criminals and the "the so-called sacred books on Islam, including the Sahah Sittah (The so-called Six Right Ones)" are nothing but piles of "shameful, irrational stories" (p. 4). Ahmed goes too far when he translates the Qurānic verses below to fit his whimsical rejection of Hadith of the Prophet Muhammad (PBUH):

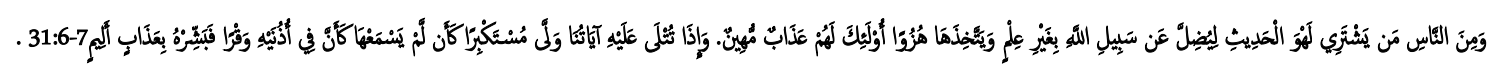

\section{Control Version}

And of the people is he who buys the amusement of speech to mislead [others] from the way of Allah without knowledge and who takes it in ridicule. Those will have a humiliating punishment. And when our verses are recited to him, he turns away arrogantly as if he had not heard them, as if there was in his ears deafness. So give him tidings of a painful punishment.

Ahmed, S

\begin{abstract}
But among people, there are those who invest their time in Hadith which is unfounded, so as to lead those without knowledge away from the path of God, making mockery of it (the Qurān). For such there is a humiliating punishment in store. Whenever Our verses are conveyed to such a purchaser of Hadith, he turns away in arrogance as if he never heard them - as if there were deafness in his ears. So give him the tidings of a painful doom.
\end{abstract}

Moreover, Ahmed (2006) argues that in order to defend the 'Imams of Hadith', some commentators try to explain away 'Lahwal Hadith' as music. This obviously makes no linguistic or contextual sense" (p. 207). Ironically, Ahmed's version of this verse is a naïve distortion that lacks linguistic and contextual clues as well as common sense.

Commenting on the mainstream Muslims' perspective stance that a Muslim must obey Allah (SWT) and the Messenger (PBUH), The Monotheist Group (2012) maintains that 
What has been presented thus far is the logic used in justifying the opening of Pandora's Box [a source of many unforeseen troubles] where the definition of "what" the messenger delivered becomes a treasure hunt through the hundreds of thousands of old wives' tales and stories all attributed to the messenger doing or saying something (p.36).

And according to the Reformists, Muslims have "sanctified a collection of medieval hearsay reports and traditions attributed to Muhammad. Unfortunately, this was accomplished through the distortion of the meaning of several Qurānic verses regarding the role of the prophet" The reason for their peculiar translation of the relevant verse is the conviction that "God explains the Koran, and makes no mention of Muhammad or any other prophet, or indeed any human explanation whatsoever" (Yuksel, 2003, pp.20-21).

\section{Major Findings and Implications}

1) All the six cases isolated in this article prove the strong and significant role of ideological and sectarian bias in shaping the course of translating the Qurān in English.

2) Drastic variations such as the use of the feminine pronoun 'she' for Allah (SWT) and the gnostic readings in Khalifa's 'Authorized Version' are essentially ideologically-motivated.

3) The 'gender-neutral' language [use of the pronoun $\mathbf{H u}$ and the combination $\mathbf{H e} / \mathbf{S h e}$ in reference to Allah (SWT)] in translating the Qurān reflects complex traces of ideology as it is not motivated by the feminist movement alone. The case of Helminski, for instance, shows how the translator's cultural and linguistic backgrounds, Sufi doctrines, and feminist agenda all combine to produce an extremely radical and alien reading of the Qurān in English with regard to 'gender-neutral' issues.

4) The 'gender-neutral' approach in translating the Qurān contributes to the unjustified loss of core stylistic and discoursal features that are peculiar to the SL text. In Tarazi's version, for example, changing the system of pronouns in the Qurān would alter the essence of the Qurānic message.

5) In some instances, as in Rashad's Khalifa's versions discussed in case (3), it seems that ideology is the sole raison d'être for of translating the Qurān. Khalifa's Qurānist translation shows strong tendencies to re-interpret the Qurān in line with his gnostic claim of being the 'Messenger of the Covenant' and his rejection of the Prophet Muhammad's (PBUH) Hadith and Suna.

6) Sufi perspectives have their own legacy in interpreting particular personal pronouns to support certain Sufi and gnostic beliefs.

7) In translating the Qurān, ideological agendas may sometimes produce fictional scenarios which the SL text never accommodates.

8) Neo-Mutazilte schemata contribute to some types of distortion in translating some personal pronouns in order to negate some miraculous events narrated in the Qurān.

9) The Qurānist traces of ideology are manifest in case (6). Within the ideological schemata of the Qurānists, the Prophet (PBUH) is only "a mailman of God," (Yuksel, 2003, p. 472) who has no role in explaining the message communicated in the Qurān.

\section{References}

Abdel Haleem, M. A. S. (1992). Grammatical shift for the rhetorical purposes: Iltifăt and related features in the Qur'ān. Bulletin of the School of Oriental and African Studies, Volume LV, Part 3, pp. 407-432

Abdel Haleem, M.A.S. (2004). The Qurān. Oxford University Press

Ahmad, K. and Ali, S. A. (1997). Hadith: a re-evaluation. Retrieved June 15, 2012 from: http://sufism.org/wpcontent/uploads/2013/12/HADITH-a-Reevaluation.pdf

Ahmed, A. (2001). Al-Quran: a contemporary translation. Princton University Press

Ahmed, S (2007). The criminals of Islam. Retrieved February 27, 2013 from: http://drshabbir.com/library/criminals.pdf

Ahmed, S. (2006). Islam: the true history and false beliefs. Retrieved January 12, 2015 from: http://www.justislam.co.uk/images/True\%20History\%20And\%20False\%20Believes.pdf

Ahmed, S. (2014). Divine feminine in Islam. Retrieved May 18, 2014 from: http://zoya-thewayofasufi.blogspot.com/

Aichele, G. (2002). Translation as de-canonization: Matthew's Gospel according to Pasolini. Retrieved February 8, 2013 from: http://home.comcast.net/ gcaichele/writings/pasolinimatthew.pdf

Arberry, A.J. (1996). The Koran interpreted. Touchstone.

Asad, M. (1980). The message of the Qurān. Gibraltar: Dar Al-Andlus.

Bakhtiar, L. (2009). The sublime Qurān. Kazi Publication.

Busool, A.N. (2011). The wise Qurān: a new translation. Xlibris Corporation.

Dawood, N. J. (2006). The Koran. Penguin Books.

De Waard, J. and E. Nida, A. (1986). From one language to another: functional equivalence in Bible translating. Nashville: Nelson.

Dörnyei, Z. (2007) Research methods in applied linguistics. Oxford University Press 
Galian, L. (2004). The centrality of the divine feminine in Sufism. Published in the Proceedings of the "2nd Annual Hawaii International Conference on Arts and Humanities, Honolulu, Hawaii. Retrieved April 12, 2013 from: http://www.surrenderworks.com/library/imports/divinefeminine.html

Hassen, R. (2011). English translation of the Qurān by women: the challenges of "gender balance" in and through language. MonTI, 3, 211-230.

Hatim B. and Mason, I. (1997). The translator as communicator. London, Routledge

Helminski, C.A. (2000). The light of dawn: daily readings from the holy Qurān. Shambhala Threshold Book.

Herrag, E. (2012). The ideological factor in the translation of sensitive issues from the Qurān into English, Spanish and Catalan. A doctoral thesis at Universitat Autònoma de Barcelona, Departament de Traduccio i Interpretacio.

Hidayatullah, A. A. (2014). Feminist edges of the Qurān. Oxford University Press.

Hulusi, A. and A. Atalay (2013). Decoding the Quran: a unique Sufi interpretation. Decoding the Quran.

Jaffer, M. (2007)."Rumi and the sacred feminine." Retrieved, December 12, 2012 from:

http://www.boloji.com/index.cfm?md=Content\&sd=Articles\&ArticleID=2399

Khalifa, R. (2005). Qurān: the final testament, authorized English version with Arabic text. Submission Org.

Khalifa, R. (2010). Qurān: the final testament, authorized English version of the original. Smashwords Edition.

Kidwai, A. (2013). What is in the Qurān? Message of the Qurān in simple English. Viva Books.

Lefevere, A. (2004). Translation, rewriting and the manipulation of literary fame. Routledge.

Lyons, J. (1995). Introduction to theoretical linguistics. Cambridge University Press.

Madigan, T. (1998). A woman with perfume and prayer speaks with Christ-Sophia: Wisdom as a basis for dialogue between Christians and Muslims. A paper presented at 'Gathering the Threads' Women Scholars in Religion and Theology Conference, Brisbane, January 1998. Retrieved December 8, 2013 from: http://www.cimer.org.au/_docs/articles_by_trish/a_woman_of_perfume_and_prayer_speaks_with_christ.pdf Meyer, M. (2001). "Between theory, method, and politics: positioning of the approaches to CDA.” In Wodak, R. and M. Meyer (Eds.), Methods of Critical Discourse Analysis, Sage Publications, pp. 14-31.

Monotheist Group. (2012). The Qurān: a monotheist translation. USA: Bainbow Press.

Nicholson, R. A. (Trans.) (2002). The Mathnawi Jalaluddin Rumi. Gibb Memorial Trust, 2002, V:701.

Petrescu, C. (2009). Ideology and translation. Professional Communication and Translation Studies, 2(1-2), 93-96.

Poythress, V. and G. Grudem (2000). The gender-neutral Bible controversy: muting the masculinity of God's words. Broadman and Holman Publishers.

Qurān. Islamawakened. Retrieved October 10, 2013 from: http://islamawakened.com/quran/

Rafiabadi, H. N. (2003). World religions and Islam: a critical study, part I. Sarup and Sons.

Robinson, N. (2007). Sectarian and ideological bias in Muslim translations of the Qurān. Islam and Christian-Muslim Relations, 8(3), 261-278.

Saheeh International (2010). The translation of the Qurān. Al-Muntada Al-Islami Trust.

Shorter Oxford English Dictionary (2007). Oxford University Press.

Sideeg, A.I. (2014). Sources of linguistic variations in the translation of the Qurān: a critical discourse analysis of eighty versions of the Qurān in English. Unpolished PhD Thesis at OIU.

Starkovsky, N. (2005). The Koran handbook: an annotated translation. Algora Publishing, New York.

Strauss, L. (2008). Why the English standard version (ESV) should not become the standard English version. Retrieved September 11, 2013 from: http://betterbibles.com/2008/11/21/why-the-english-standard-version-esv-should-notbecome-the-standard-english-version-by-mark-strauss/

Tarazi, O. (2012). Allah's Words in plain English. Independent Publisher

Tavakoli, H. (2013), A dictionary of research methodology and statistics in applied linguistics. Rahnama Press.

Thomas, R. L (2002). Dynamic equivalence: a method of translation or a system of hermeneutics? In R. L. Thomas (ed.) Evangelical Hermeneutics: The New Versus the Old, pp. 81-112. Kregel Academic.

Tymoczko, M. and Gentzler, E. (eds.). (2002). Translation and power. Amherst, MA: University of Massachusetts Press Van Dijk T. A. (2006). Ideology and discourse analysis. Journal of Political Ideology, 11(2), 115-140.

Van Dijk, T. A. (2001). Multidisciplinary CDA: a plea for diversity. In R. Wodak and M. Meyer (Eds.), Methods of critical discourse analysis. London: Sage Publications.

Wodak, R. (2009). Critical discourse analysis: history, agenda, theory, and methodology. In R. Wodak, and M. Meyer (Eds.), Methods for Critical Discourse Analysis. (pp. 1-33).

Wodak, R., and Meyer, M. (Eds.). (2009). Methods of critical discourse analysis. Sage.

Yuksel, E. (2003)."The Qurān: a reformist translation: eight unique features." Retrieved April 18, 2014 from: http://www.yuksel.org/e/books/rtq.htm.

Yuksel, E., al-Shaiban, L. S., and Schulte-Nafeh, M. (2007). Reformist translation. Brainbow Press.

\section{Arabic References}

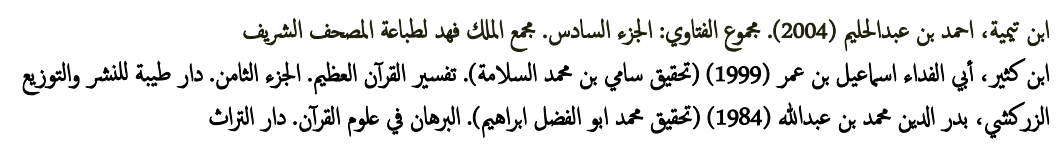

